\title{
Antibody response to COVID-19 vaccination in patients with lymphoma
}

\author{
Kentaro Narita ${ }^{1}$ - So Nakaji ${ }^{2}$. Rikako Tabata ${ }^{1}$ - Toshiki Terao ${ }^{1}$ - Ayumi Kuzume ${ }^{1}$ - Takafumi Tsushima ${ }^{1}$. \\ Daisuke Ikeda ${ }^{1}$ - Ami Fukumoto ${ }^{1}$ - Daisuke Miura ${ }^{1}$ - Masami Takeuchi ${ }^{1} \cdot$ Masahiro Doi $^{3} \cdot$ Yuka Umezawa $^{3}$. \\ Yoshihito Otsuka ${ }^{3} \cdot$ Hiroyuki Takamatsu ${ }^{4} \cdot K_{\text {Kosei Matsue }}^{1}{ }^{10}$
}

Received: 27 December 2021 / Revised: 3 February 2022 / Accepted: 3 February 2022 / Published online: 21 February 2022

(c) Japanese Society of Hematology 2022

\begin{abstract}
Patients with lymphoma are at increased risk for severe acute respiratory syndrome coronavirus 2 (SARS-CoV-2); therefore, evaluation of SARS-CoV-2 vaccination efficacy is essential. We conducted a prospective observational study to monitor the antibody response in 500 patients with lymphoma after SARS-CoV-2 vaccination. Antibody levels increased in a stepwise manner after the first and second dose of the vaccine. After completion of the two-dose series, anti-S antibody was negative in 109 patients (21.8\%), and below clinically protective levels (anti-S $\geq 264 \mathrm{U} / \mathrm{mL}$ ) in 236 patients $(47.2 \%$ ). The median anti-S titers at 0-6 months, 7-12 months, 13-24 months, and 24 months after treatment completion were $0.4 \mathrm{U} / \mathrm{mL}, 3.8 \mathrm{U} / \mathrm{mL}, 270$ $\mathrm{U} / \mathrm{mL}$, and $650 \mathrm{U} / \mathrm{mL}$, respectively. Multivariate analysis showed that receiving the vaccine $<6$ months since completing treatment, white blood cell count $<5050 / \mu \mathrm{L}$, percentage of CD19+ cells $<10 \%$, CD $4+$ cells $<27 \%$, immunoglobulin $(\mathrm{Ig})$ $\mathrm{A}<195 \mathrm{mg} / \mathrm{dL}, \mathrm{IgM}<50 \mathrm{mg} / \mathrm{dL}$, serum soluble interleukin 2 receptor $>600 \mathrm{U} / \mathrm{mL}$, and presence of lymphoma cells in the peripheral blood were significantly correlated with anti-S $<264 \mathrm{U} / \mathrm{mL}$. Lymphoma patients had variably impaired antibody response to the SARS-CoV-2 vaccine. We identified various factors to predict COVID-19 vaccine effectiveness in lymphoma patients that may help tailoring possible vaccine boosters.
\end{abstract}

Keywords COVID-19 · COVID-19 vaccine $\cdot$ Lymphoma

\section{Introduction}

The emerging pandemic of severe acute respiratory syndrome virus 2 (SARS-CoV-2) has affected tens of millions of individuals and caused many deaths since the first discovery of patients in Wuhan, China in 2019 [1]. Several types of vaccines for SARS-CoV-2 have been developed and their effectiveness has been verified in clinical trials [2-5].

Kosei Matsue

koseimatsue@gmail.com

1 Division of Hematology/Oncology, Department of Medicine, Kameda Medical Center, Kamogawa, Chiba, Japan

2 Department of Gastroenterology, Kameda Medical Center, Kamogawa, Chiba, Japan

3 Central Laboratory, Kameda Medical Center, Kamogawa, Chiba, Japan

4 Department of Hematology, Faculty of Medicine, Institute of Medical, Pharmaceutical and Health Sciences, Kanazawa University, Kanazawa, Ishikawa, Japan
A Lipid nanoparticle-encapsulated mRNA-based vaccine generates a high titer of a neutralizing antibody for SARSCoV-2 [6], and a high effectiveness against even the delta variant of SARS-CoV-2 has been reported [7]. SARS-CoV-2 vaccine effectiveness is estimated to be similar between healthy populations and non- immunocompromised populations with underlying conditions, such as asthma, obesity, hypertension and diabetes, without immunocompromised nature; however, patients with immunocompromised patients have shown less vaccine effectiveness of $39.1 \%$ than the immunocompetent cohort [8]. Low antibody responses have been also reported in patients with lymphoid malignancies especially in patients undergoing active treatment with anti-CD20 antibodies or Bruton's tyrosine kinase inhibitors (BTKi) [9-13]. This weak antibody response to vaccination may persist until 12 months after completion of anti-CD20 antibody or BTKi therapies (CD20/BTKi) [10, 12]. In addition to the type of treatment, several clinical factors related to weak vaccine responses have been suggested in some studies with relatively small numbers of patients $[10,14]$. To 
address these issues in patients with lymphoma, we prospectively measured antibody titers to two COVID-19 vaccine (BNT162b2 mRNA coronavirus disease 19 [COVID-19] and mRNA1273 SARS-CoV-2 vaccine) in patients with lymphoma who had previously been treated or were undergoing treatment. The primary objective of this report was to evaluate the serological response to the SARS-CoV-2 vaccine and to investigate the clinical variables related to vaccine responses in patients with various types of lymphoma.

\section{Methods}

\section{Participants and sample collection/analysis}

Serum samples were collected from patients with lymphoma (Hodgkin disease [HD], non-Hodgkin lymphoma, and chronic lymphocytic leukemia/small lymphocytic lymphoma [CLL/SLL]) with no known history of SARSCoV-2 infection between June and October 2021 at Kameda Medical Center, and Kanazawa University, both located in Japan. Blood samples were obtained before the first dose and second dose (the latter of which was administered at least 2 weeks after the first dose) and 3-8 weeks after the second dose of vaccination, and the titers of antibodies against SARS-CoV-2 were compared. We obtained patient characteristics including age, sex, type of lymphoma, type of treatment, time between receiving the last treatment and receiving a second dose of the vaccine (time from treatment), white blood cell count (WBC), serum concentration of immunoglobulin-G ( $\operatorname{Ig} \mathrm{G})$, immunoglobulin-A ( $\operatorname{Ig} \mathrm{A})$, immunoglobulin-M (IgM), and soluble interleukin 2 receptor (sIL2-R), and the percentages of lymphocytes positive for $\mathrm{CD} 3, \mathrm{CD} 4, \mathrm{CD} 8$, and $\mathrm{CD} 19$. We reviewed the relationship between these factors and the titers of antibodies against SARS-CoV-2 after the second dose of vaccination as a primary objective. The patients received vaccination through the national Japanese vaccination program. We also measured antibody titers in the serum of age-matched controls 4-8 weeks after two doses of vaccination. Blood samples were collected as a routine clinical practice and preserved at $-80{ }^{\circ} \mathrm{C}$ until the time of analysis. Elecsys Ati-SARSCoV-2 assay on Cobas e801 (Roche Diagnostics KK) was used for the quantification of IgG against the SARS-CoV-2 spike protein (anti-S). Concentrations of anti-S $\geq 0.80 \mathrm{U} /$ $\mathrm{mL}$ were considered as positive and anti-S $\geq 264 \mathrm{U} / \mathrm{mL}$ was considered as a clinically protective level of antibody titer for SARS-CoV-2 virus infection, according to a previous report [15]. Correlations between the clinical variables and vaccine responses were compared. We analyzed the clinical factors that significantly affected the vaccine response of anti-S $\geq 264 \mathrm{U} / \mathrm{mL}$ using univariate and multivariate analyses. Patients receiving active treatment and those with a history of chemotherapy or chemo-immunotherapy were classified as the "treatment group," and patients with aggressive lymphoma or patients with indolent lymphomas who were being cautiously monitored, but who had completed vaccination before treatment commencement were classified as the "untreated group." This study was approved by Institutional Review Board and conducted according to the declaration of Helsinki. All participants provided informed consent.

\section{Statistical analysis}

Comparison of three or more continuous variables was performed using the Kruskal-Wallis test. Categorical variables were compared using Fisher's exact test. Receiver operating characteristic (ROC) curve analysis was performed to determine the optimal cut-off of clinical variables for obtaining anti-S $\geq 264 \mathrm{U} / \mathrm{mL}$. A logistic regression model was used for multivariate analysis. The Kaplan-Meier method and logrank test were applied to compare the cumulative hazard ratio to achieve anti-S $\geq 264 \mathrm{U} / \mathrm{mL}$ at different time points from the last treatment. Missing values were imputed using the k-nearest neighbor method. All $P$ values were two-sided, and $P<0.05$ was considered to be statistically significant. $P$ values between three or more sets were adjusted using the Benjamini-Hochberg method for controlling the false discovery rate [16]. All statistical analyses were performed using R (version 4.1.1; R Foundation, Vienna, Austria).

\section{Results}

\section{Patient characteristics and vaccine response}

Between 27 June 2021 and 20 October 2021, a total of 500 patients with lymphoma who had completed two doses of SARS-CoV-2 vaccination were included in the study. Patient demographics and clinical characteristics according to the achievement of antibody positivity (anti-S $\geq 0.8 \mathrm{U} / \mathrm{mL}$ ) and clinically relevant antibody levels (anti-S $\geq 264 \mathrm{U} / \mathrm{mL}$ ) are shown in Table 1 . The lymphoma subtypes were: diffuse large B cell lymphoma (DLBCL, $n=212$ ), follicular lymphoma (FL, $n=134$ ), indolent B cell lymphoma other than FL (indBCL, $n=83$ ), including marginal zone lymphoma $(n=46)$, Waldenström macroglobulinemia $(n=16)$, chronic lymphocytic leukemia $(n=16)$, and low-grade unclassifiable BCL $(n=5)$; T cell lymphoma (TCL, $n=36)$, Hodgkin disease $(n=20)$, and other aggressive BCL other than DLBCL (aggBCL, $n=15)$, including mantle cell lymphoma ( $n=10)$, and Burkitt lymphoma (BL, $n=5$ ). All 500 patients received two doses of vaccination. Four hundred and ninety one $(98.2 \%)$ patients received the BNT162b2 mRNA COVID-19 vaccine and nine (1.8\%) received mRNA1273 
Table 1 Clinical characteristics of patients according to the SARS-CoV-2 antibody titer

\begin{tabular}{|c|c|c|c|c|c|}
\hline Variables & All patients & $\begin{array}{l}\text { Anti-S } \\
<0.8 \mathrm{U} / \mathrm{mL}\end{array}$ & $\begin{array}{l}\text { Anti-S } \\
\geq 0.8 \mathrm{U} / \mathrm{mL}\end{array}$ & $\begin{array}{l}\text { Anti-S } \\
<264 \mathrm{U} / \mathrm{mL}\end{array}$ & $\begin{array}{l}\text { Anti-S } \\
\geq 264 \mathrm{U} / \mathrm{mL}\end{array}$ \\
\hline Number of patients (\%) & 500 & $109(21.8)$ & $391(78.2)$ & $236(47.2)$ & $264(52.8)$ \\
\hline Age, median (range) & $73(18-92)$ & $74(54-92)$ & $71(18-92)$ & $75(39-92)$ & $70(18-91)$ \\
\hline \multicolumn{6}{|l|}{$\operatorname{Sex}, n(\%)$} \\
\hline Male sex (\%) & $260(52.1)$ & $60(11.1)$ & $196(39.2)$ & $94(20.7)$ & $141(31.1)$ \\
\hline \multicolumn{6}{|l|}{ Lymphoma subtype, $n,(\%)$} \\
\hline DLBCL & $212(42.4)$ & $44(8.8)$ & $168(33.6)$ & $93(18.6)$ & $119(23.8)$ \\
\hline Other aggressive BCL & $15(3.0)$ & $8(1.6)$ & $7(1.4)$ & $12(2.4)$ & $3(0.6)$ \\
\hline FL & $134(26.8)$ & $29(5.8)$ & $105(21.0)$ & $60(12.0)$ & $74(14.8)$ \\
\hline Other indolent BCL & $83(16.6)$ & $24(4.8)$ & $59(11.8)$ & $45(9.0)$ & $38(7.6)$ \\
\hline HD & $20(4.0)$ & $1(0.2)$ & $19(3.8)$ & $5(1.0)$ & $15(3.0)$ \\
\hline TCL & $36(7.2)$ & $3(0.6)$ & $33(6.6)$ & $21(4.2)$ & $15(3.0)$ \\
\hline \multicolumn{6}{|l|}{ Treatment, $n(\%)$} \\
\hline CD20 \pm chemo-Tx & $327(65.4)$ & $85(17.0)$ & $242(48.4)$ & $153(30.6)$ & $174(34.8)$ \\
\hline BTKi & $14(2.8)$ & $9(1.8)$ & $5(1.0)$ & $13(2.6)$ & $1(0.2)$ \\
\hline Combination chemotherapy & $45(9.0)$ & $3(0.6)$ & $42(8.4)$ & $20(4.0)$ & $25(5.0)$ \\
\hline CAR-T & $1(0.2)$ & $1(0.2)$ & 0 & $1(0.2)$ & 0 \\
\hline ASCT & $26(5.2)$ & $5(1.0)$ & $21(4.2)$ & $11(2.2)$ & $15(3.3)$ \\
\hline Allo-SCT & $11(2.2)$ & $2(0.4)$ & $9(1.8)$ & $5(1.0)$ & $6(1.2)$ \\
\hline Active treatment & $101(20.2)$ & $78(15.6)$ & $23(4.6)$ & $99(19.8)$ & $2(0.4)$ \\
\hline Untreated & $89(17.8)$ & $5(1.0)$ & $84(16.8)$ & $40(8.0)$ & $49(9.8)$ \\
\hline $\begin{array}{l}\text { Time from last Tx, median } \\
\text { (range) [month] }\end{array}$ & $40(0-271)$ & $3(0-169)$ & $56(0-271)$ & $6(0-169)$ & $66(1-271)$ \\
\hline \multicolumn{6}{|l|}{ Blood test, median (range) } \\
\hline $\mathrm{WBC}\left[\times 10^{3} / \mu \mathrm{L}\right]$ & $5.3(4.9-74.5)$ & $4.6(3.9-74.5)$ & $5.4(4.9-50.9)$ & $5.1(3.9-74.5)$ & $5.4(4.9-16.9)$ \\
\hline Lymphocyte [\%] & $30(2-97)$ & $24(4-97)$ & $31(2-94)$ & $26(2-97)$ & $32(8-64)$ \\
\hline CD3 [\%] & $61(2-98)$ & $74(2-94)$ & $59(3-98)$ & $69(2-98)$ & $58(23-98)$ \\
\hline CD4 [\%] & $28(1-67)$ & $26(1-53)$ & $28(2-67)$ & $26(1-62)$ & $30(2-67)$ \\
\hline CD8 [\%] & $26(1-80)$ & $40(1-80)$ & $24(1-73)$ & $34(1-80)$ & $23(6-67)$ \\
\hline CD19 [\%] & $11(0-97)$ & $0(0-97)$ & $14(0-96)$ & $3(0-97)$ & $16(0-69)$ \\
\hline $\mathrm{IgG}$ [mg/dL] & $1116(55-5887)$ & $779(55-2278)$ & $1175(71-5887)$ & $1018(55-5887)$ & $1211(71-2597)$ \\
\hline $\operatorname{IgA}[\mathrm{mg} / \mathrm{dL}]$ & $189(3-1369)$ & $112(3-549)$ & $216(3-1369)$ & $143(3-1052)$ & $230(3-1369)$ \\
\hline IgM [mg/dL] & $62(1-5362)$ & $29(1-3815)$ & $70(8-5362)$ & $45(1-5362)$ & 73 (8-2980) \\
\hline sIL2R [U/mL] & $519(147-9453)$ & $564(147-5153)$ & $504(178-9453)$ & $612(147-9453)$ & $468(178-5918)$ \\
\hline
\end{tabular}

Anti-S severe acute respiratory syndrome coronavirus 2 spike protein antibodies, $D L B C L$ diffuse large B cell lymphoma, $B C L \mathrm{~B}$ cell lymphoma, $F L$ follicular lymphoma, $H D$ Hodgkin disease, chemo-Tx chemotherapy, BTKi Bruton's tyrosine kinase inhibitor, $C A R-T$ chimeric antigen receptor therapy, $A S C T$ autologous stem cell transplantation, Allo-SCT allogeneic stem cell transplantation, $W B C$ white blood cell, $I g$ immunoglobulin, sIL2R soluble interleukin 2 receptor

SARS-CoV-2, respectively. One-hundred age-matched volunteers without a history of immunosuppressive agents or antineoplastic drugs served as controls. Among the 500 patients, $411(82.2 \%)$ had received treatment for lymphoma. One hundred and one patients $(20.2 \%)$ received vaccination within 6 months of treatment. Of the patients, 26 (5.2\%), 11 $(2.2 \%)$, and $1(0.2 \%)$ had a history of receiving autologous stem cell transplantation, allogenic stem cell transplantation, and chimeric antigen receptor $\mathrm{T}$ cells, respectively. None of these patients received vaccinations within 6 months of therapy. At the time of vaccination, patients were either in complete remission $(n=365,88.8 \%)$, partial remission $(n=44,10.7 \%)$, or clinical relapse $(n=2,0.4 \%)$. Eightynine patients did not receive any antineoplastic treatment (untreated group); of these, 72 were being monitored for the development of indolent lymphoma, and 17 had aggressive lymphoma, but vaccine administration was completed before treatment commenced.

None of the participants had a history of SARS-CoV-2 infection and this was confirmed by negative anti- $\mathrm{N}$ assays. Seropositivity of anti-S antibodies after two doses of vaccination ( $\geq 0.8 \mathrm{U} / \mathrm{mL}$ ) was achieved in 391 patients $(78.2 \%)$, 
while 109 patients $(21.8 \%)$ remained negative. Two hundred and sixty four patients (52.8\%) achieved clinically relevant levels of anti-S ( $\geq 264 \mathrm{U} / \mathrm{mL})$ and the remaining 236 $(47.2 \%)$ did not.

In terms of obtaining a clinically relevant antibody titer, it was important whether the patient was treated within 6 months, and there was no association with the type of lymphoma treatment. Figure 1 shows the relationship between anti-S antibody levels before vaccination and after two doses of vaccination. Treated patients were further divided into five groups according to when they had received their last treatment: within the previous 6 months (median anti-S titer: $0.4 \mathrm{U} / \mathrm{mL}$ ), 7-12 months ( $3.8 \mathrm{U} / \mathrm{mL}), 13-24$ months (339 U/ $\mathrm{mL})$, and more than 24 months ago $(659 \mathrm{U} / \mathrm{mL})$. Untreated patients had a median titer of $318 \mathrm{U} / \mathrm{mL}$. Notably, only two out of 102 patients receiving active treatment achieved an anti-S titer $\geq 264 \mathrm{U} / \mathrm{mL}$. Antibody titers were significantly higher in patients who received their vaccine after completing their treatment more than 12 months ago compared to those who completed treatment less than 12 months previously $(3.8 \mathrm{U} / \mathrm{mL}$ vs. $339 \mathrm{U} / \mathrm{mL}, p<0.01)$.

Of the patients treated, 10 out of $83(12 \%)$ for whom a pre-vaccinated sample was available were seropositive, whereas none of the untreated patients or healthy subjects were seropositive for anti-S prior to vaccination. Antibody levels increased in a stepwise manner before, after the first, and after the second dose of vaccine (median: $0.4 \mathrm{U} / \mathrm{mL}$ [interquartile range 0.4-0.4], $0.4 \mathrm{U} / \mathrm{mL}$ [0.4-5.1], and 324.5 $\mathrm{U} / \mathrm{mL}$, [10.6-990.5], respectively, $p<0.01$ ) (Supplemental Fig. 1).

Figure 2 shows antibody levels within and more than 6 months since the last treatment in patients treated with either cytotoxic chemotherapy alone, CD20 monoclonal antibodies, or CD20/BTKi with or without cytotoxic chemotherapy. The median anti-S levels of patients who received cytotoxic chemotherapy within 6 months and after 6 months were $75 \mathrm{U} / \mathrm{mL}$ and $564 \mathrm{U} / \mathrm{mL}$, respectively. Patients who received CD20/BTKi within and after 6 months were 0.4 $\mathrm{U} / \mathrm{mL}$ and $580 \mathrm{U} / \mathrm{mL}$, respectively. There was no difference in antibody levels between the chemotherapy and CD20/ BTKi groups 6 months after the end of treatment $(p=0.88)$, but within 6 months, the former showed significantly higher anti-S levels than the latter $(p<0.01)$.

Next, we compared the antibody levels in patients with and without lymphoma cell infiltration in the peripheral blood. The group with lymphoma cell infiltration included two FL and 19 indBCL, while the group without infiltration included 212 DLBCL, 132 FL, 64 indBCL, 36 TCL, 20 HD, and 15 aggBCL. Patients with lymphoma cell infiltration in the peripheral blood had significantly lower anti-S levels than those without in both the treated and untreated groups (median $11 \mathrm{U} / \mathrm{mL}$ vs. $331 \mathrm{U} / \mathrm{mL}$ in the treated group, and

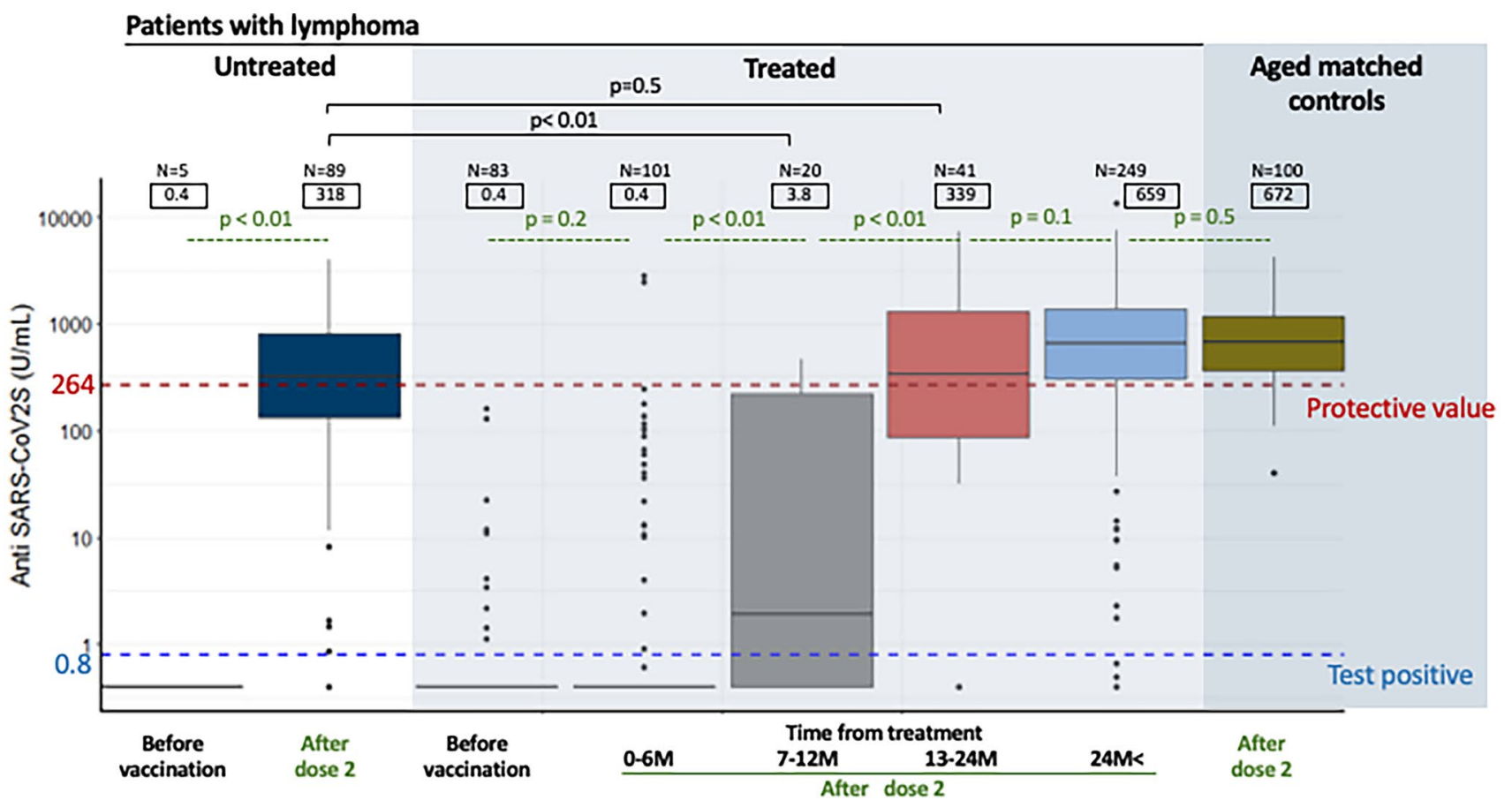

Fig. 1 Box-and-whisker plot of antibody titers after two doses of severe acute respiratory syndrome coronavirus 2 (SARS-CoV-2) vaccine in untreated and treated lymphoma patients and agematched controls. The treated groups are divided into 0-6 months,
7-12 months, 13-24 months, and 24 months and beyond according to the time since last treatment. Median values for each group are shown in squares 


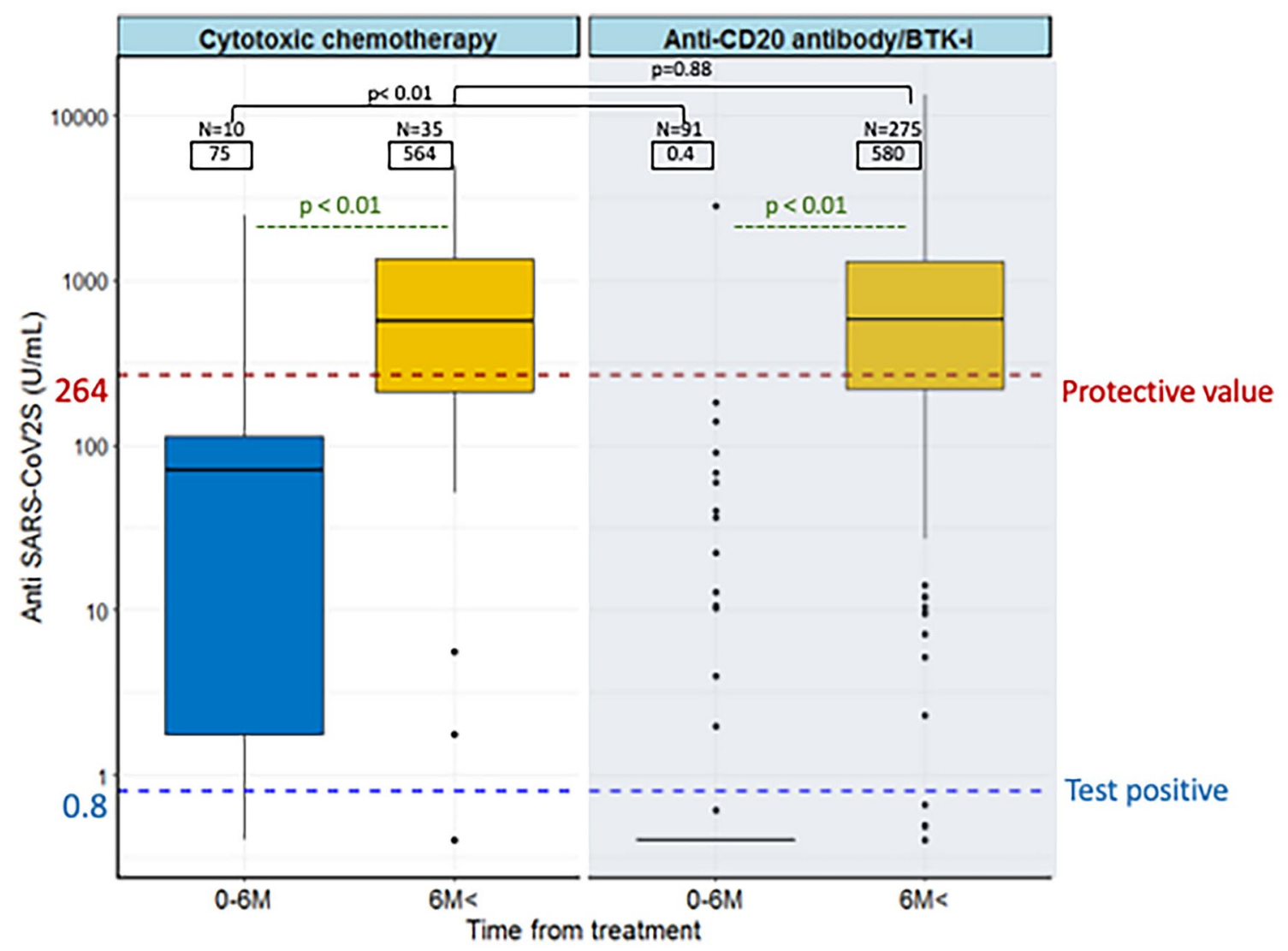

Fig. 2 Boxplots showing anti-severe acute respiratory syndrome coronavirus 2 (SARS-CoV-2) antibody titers in patients treated with cytotoxic chemotherapy alone or with CD20 antibodies or Bruton's tyrosine kinase inhibitor (BTKi) within 6 months of their last treatment and thereafter

Fig. 3 Box-and-whisker diagram showing severe acute respiratory syndrome coronavirus 2 (SARS-CoV-2) antibody titers in untreated and treated patients with and without lymphoma cell infiltration in the peripheral blood (PB). Median values for each group are shown in squares

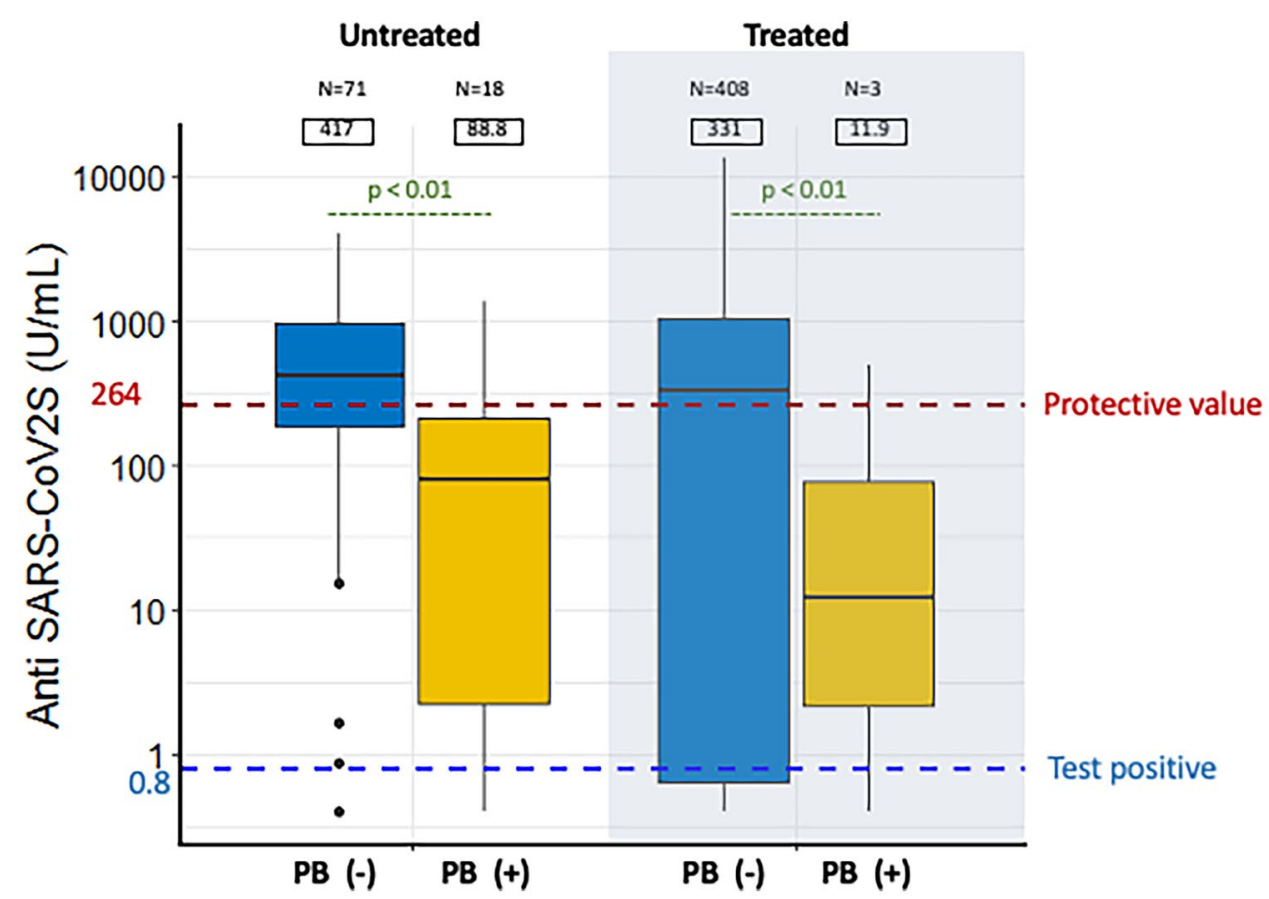


$88 \mathrm{U} / \mathrm{mL}$ vs. $417 \mathrm{U} / \mathrm{mL}$ in the untreated group, $p<0.01$ for both) (Fig. 3).

Within 6 months of treatment, anti-S antibody titers were low in all types of lymphoma (Supplementary Fig. 2). Improvement in anti-S antibody levels was observed in patients who were at least 6 months post-treatment. Overall, patients who received the vaccine more than 6 months after treatment tended to have higher antibody titers than untreated patients of the same type, especially in FL patients, who had significantly higher anti-S antibody levels than untreated patients.

The cumulative hazard ratio to obtain anti-S $\geq 264 \mathrm{U} / \mathrm{mL}$ and time from treatment according to the use of CD20/BTKi using the Kaplan-Meier hazard ratio curve showed no difference $(p=0.2)$, but indolent lymphoma (FL and indBCL) showed a delayed anti-S response against aggressive lymphoma (DLBCL, HD, TCL, and aggBCL) $(p<0.01)$ (Supplemental Fig. 3, A and B).

\section{Univariate and multivariate analysis}

Next, we examined the factors involved in the response of lymphoma patients to vaccines. Table 2 showed univariate analysis of various variables that affect the achievement of anti-S $\geq 264 \mathrm{U} / \mathrm{mL}$. Cut-off values were determined by ROC analysis (Supplemental Fig. 4, 1-2). The cut-off value of time from last treatment was set at 6 months according to a previous report [9]. Using these cut-off values, univariate analysis indicates that age, lymphocyte, CD 19, CD4, IgG, $\operatorname{IgA}$, IgM, time from treatment, sIL2-R, and lymphoma cell infiltration in the peripheral blood are significantly associated with acquisition of anti-S $\geq 264 \mathrm{U} / \mathrm{mL}$ (Table 2).

Table 2 Univariate analysis of variables associated with the achievement of anti-S $\geqq 264 \mathrm{U} / \mathrm{mL}$

\begin{tabular}{|c|c|c|c|c|c|c|c|}
\hline \multirow[t]{2}{*}{ Variable } & \multirow[t]{2}{*}{ Cut-off value } & \multicolumn{2}{|c|}{ Serologic Response, N (\%) } & \multirow[t]{2}{*}{ Total } & \multirow[t]{2}{*}{$\mathrm{P}$} & \multirow[t]{2}{*}{ OR } & \multirow[t]{2}{*}{$95 \% \mathrm{CI}$} \\
\hline & & Anti-S $<264 \mathrm{U} / \mathrm{mL}$ & Anti-S $\geqq 264 \mathrm{U} / \mathrm{mL}$ & & & & \\
\hline \multirow[t]{2}{*}{ Age } & $\geqq 73 \mathrm{yr}$ & $147(29.4)$ & $114(22.8)$ & 261 & $<0.01$ & 0.4 & $0.31-0.66$ \\
\hline & $<73 \mathrm{yr}$ & 89 (17.8) & $150(30.0)$ & 239 & & & \\
\hline \multirow[t]{2}{*}{ WBC } & $\geqq 5.1 \times 10^{3} / \mu \mathrm{L}$ & $120(24.0)$ & $157(31.4)$ & 277 & 0.06 & 1.4 & $0.97-2.05$ \\
\hline & $<5.1 \times 10^{3} / \mu \mathrm{L}$ & $116(23.2)$ & $107(21.4)$ & 223 & & & \\
\hline \multirow[t]{2}{*}{ Lymphocyte } & $\geqq 30 \%$ & $97(19.4)$ & $163(32.6)$ & 260 & $<0.01$ & 2.3 & $1.58-3.36$ \\
\hline & $<30 \%$ & $139(27.8)$ & $101(20.2)$ & 240 & & & \\
\hline \multirow[t]{2}{*}{ CD19 } & $\geqq 10 \%$ & $68(13.6)$ & $204(40.8)$ & 272 & $<0.01$ & 8.3 & $5.50-12.82$ \\
\hline & $<10 \%$ & $168(33.6)$ & $60(12.0)$ & 228 & & & \\
\hline \multirow[t]{2}{*}{ CD3 } & $\geqq 66 \%$ & $133(26.6)$ & $74(14.8)$ & 207 & $<0.01$ & 0.3 & $0.20-0.44$ \\
\hline & $<66 \%$ & $103(20.6)$ & $190(38.0)$ & 293 & & & \\
\hline \multirow[t]{2}{*}{ CD4 } & $\geqq 27 \%$ & $113(22.6)$ & $166(33.2)$ & 279 & $<0.01$ & 1.8 & $1.26-2.67$ \\
\hline & $<27 \%$ & $123(24.6)$ & $98(19.6)$ & 221 & & & \\
\hline \multirow[t]{2}{*}{$\operatorname{IgG}$} & $\geqq 1090 \mathrm{mg} / \mathrm{dL}$ & $94(18.8)$ & $169(33.8)$ & 263 & $<0.01$ & 2.6 & $1.84-3.92$ \\
\hline & $<1090 \mathrm{mg} / \mathrm{dL}$ & $142(28.4)$ & $95(19.0)$ & 237 & & & \\
\hline \multirow[t]{2}{*}{$\operatorname{IgA}$} & $\geqq 195 \mathrm{mg} / \mathrm{dL}$ & $78(15.6)$ & $165(33.0)$ & 243 & $<0.01$ & 3.3 & $2.29-4.96$ \\
\hline & $<195 \mathrm{mg} / \mathrm{dL}$ & 158 (31.6) & $99(19.8)$ & 257 & & & \\
\hline \multirow[t]{2}{*}{$\operatorname{IgM}$} & $\geqq 50 \mathrm{mg} / \mathrm{dL}$ & $110(22.0)$ & $205(41.0)$ & 315 & $<0.01$ & 3.9 & $2.65-5.97$ \\
\hline & $<50 \mathrm{mg} / \mathrm{dL}$ & $126(25.2)$ & $59(11.8)$ & 185 & & & \\
\hline \multirow[t]{2}{*}{ Time from treatment } & $>6$ months & 97 (23.6) & $213(51.8)$ & 310 & $<0.01$ & 8.3 & $5.24-13.4$ \\
\hline & $\leqq 6$ months & 99 (24.6) & $2(0.4)$ & 101 & & & \\
\hline \multirow[t]{2}{*}{ sIL2-R } & $\geqq 600 \mathrm{U} / \mathrm{mL}$ & $123(24.6)$ & $68(13.6)$ & 191 & $<0.01$ & 0.3 & $0.21-0.47$ \\
\hline & $<600 \mathrm{U} / \mathrm{mL}$ & $113(22.6)$ & $196(39.2)$ & 309 & & & \\
\hline \multirow[t]{2}{*}{ PB involvement } & $(+)$ & $17(3.4)$ & $4(0.8)$ & 21 & $<0.01$ & 0.1 & $0.04-0.62$ \\
\hline & $(-)$ & $219(43.8)$ & $260(52.0)$ & 479 & & & \\
\hline \multirow[t]{3}{*}{ Treatment } & Anti-CD20 /BTKi & $176(35.2)$ & $190(38.0)$ & 366 & 0.81 & 0.8 & $0.53-1.43$ \\
\hline & Cytotoxic chemotherapy & $20(4.0)$ & $25(5.0)$ & 45 & & 1.02 & $0.46-2.24$ \\
\hline & Untreated (reference) & $40(8.0)$ & $49(9.8)$ & 89 & & 1 & - \\
\hline
\end{tabular}

Anti-S severe acute respiratory syndrome coronavirus 2 spike protein antibodies, $O R$ odds ratio, $W B C$ white blood cell, $I g$ immunoglobulin, $s I L 2 R$ soluble interleukin 2 receptor, $P B$ peripheral blood, anti-CD20/BTKi anti-CD20 monoclonal antibody therapy and/or Bruton's tyrosin kinase inhibitor therapy 
In a multivariate analysis, all of the variables used in the univariate analysis were included except for time from treatment $\geq 6$ months and the use of anti-CD20 /BTK-i, both of which had collinearity with percentage of CD19. Age, WBC, CD19, CD4, IgA $\geq$, IgM, sIL2-R and lymphoma cell infiltration in the peripheral blood were remained as an independent factors for the achievement of anti-S $\geq 264 \mathrm{U} / \mathrm{mL}$ after two doses of vaccination (Table 3).

\section{Discussion}

In this study, we showed that anti-S titers in patients with lymphoma progressively increased according to the number of vaccinations, but remained lower than in the aged matched controls. We investigated the relationship between clinical variables and the anti-S antibody response. Multivariate analysis revealed a variety of factors that were involved in the production of clinically relevant SARS-CoV-2 antibodies after vaccination. The time between the last treatment and vaccination, and the percentage of CD19-positive cells in the peripheral blood was important determinant for the clinically effective vaccine response. Our observations are in line with the previous reports that the patients treated with CD20/BTKi treatment are unable to mount a meaningful immune response to vaccine $[12,17,18]$. In addition, we have found that $10 \%$ of $\mathrm{B}$ cells in the peripheral blood are required for clinically relevant antibody production. Anti-S antibody titers were found to be extremely low if the last treatment had been administered within a year before vaccination, with a median of $0.4 \mathrm{U} / \mathrm{mL}$ within 6 months and $3.8 \mathrm{U} / \mathrm{mL}$ within $7-12$ months from the final treatment. Furthermore, the median antibody titer at 12-24 months was still low at $339 \mathrm{U} / \mathrm{nL}$ and did not reach the median of 672

Table 3 Multivariate analysis of variables associated with achievement of anti-S $\geqq 264 \mathrm{U} / \mathrm{mL}$

\begin{tabular}{lllr}
\hline Variable & OR & $95 \% \mathrm{CI}$ & $\mathrm{P}$ \\
\hline Age $\geqq 73$ yr & 0.61 & $0.37-0.98$ & 0.04 \\
WBC $\geqq 5.1 \times 10^{3} / \mu \mathrm{L}$ & 1.68 & $1.04-2.73$ & 0.03 \\
Lymphocyte $\geqq 30 \%$ & 2 & $1.24-3.25$ & $<0.01$ \\
$\mathrm{CD} 19 \geqq 10 \%$ & 4.23 & $2.54-7.14$ & $<0.01$ \\
$\mathrm{CD} 3 \geqq 66 \%$ & 1 & $0.57-1.79$ & 0.98 \\
$\mathrm{CD} 4 \geqq 27 \%$ & 1.84 & $1.12-3.05$ & 0.01 \\
$\mathrm{IgG} \geqq 1090 \mathrm{mg} / \mathrm{dL}$ & 1.45 & $0.88-2.39$ & 0.13 \\
IgA $\geqq 195 \mathrm{mg} / \mathrm{dL}$ & 1.9 & $1.14-3.16$ & 0.01 \\
IgM $\geqq 50 \mathrm{mg} / \mathrm{dL}$ & 2.47 & $1.51-4.06$ & $<0.01$ \\
sIL2-R $\geqq 600 \mathrm{U} / \mathrm{mL}$ & 0.43 & $0.26-0.70$ & $<0.01$ \\
PB involvement $(+)$ & 0.11 & $0.02-0.38$ & $<0.01$ \\
\hline
\end{tabular}

$O R$ odd ratio, $C I$ confidence interval, $W B C$ white blood cell, sIL2R soluble interleukin 2 receptor, $P B$ peripheral blood
$\mathrm{U} / \mathrm{mL}$, as in healthy subjects, until 24 months later. Both CD20/BTKi and cytotoxic chemotherapy require similar durations to obtain anti-S levels $\geq 264 \mathrm{U} / \mathrm{mL}$ (Fig. 2). The results showed that the decrease in antibody production was more pronounced with CD20/BTKi than with cytotoxic chemotherapy administered within 6 months of vaccination, but there was no difference in recovery after more than 6 months.

Patients with aggressive lymphoma showed earlier recovery of the anti-S response after treatment than patients with indolent lymphoma (Supplemental Fig. 3). The reason for the delay in vaccine response in indolent lymphoma remained unclear; we speculate that this is because maintenance therapy with CD20 is often used in indolent lymphoma. BNT162b1, which encodes a secreted trimerized SARS-CoV-2 receptor-binding domain, a pre-product of BNT162b2 mRNA COVID-19 vaccine or COVID-19 infection expanded the CD4-positive $\mathrm{T}$ cell fraction and induced T Helper-1 cell responses [19, 20]. In this study, baseline percentage of CD4-positive $\mathrm{T}$ cells before vaccination was significantly associated with the antibody response to vaccination.

Univariate and multivariate analyses were performed to identify the clinical factors that contribute to clinically protective antibody titers. Various factors, including age, were significant in univariate analysis, but in multivariate analysis, WBC, lymphocyte percentage, CD19, CD4, IgA, IgM, sIL2R, and peripheral blood infiltration of lymphoma cells remained independent factors. WBC may be related to chemotherapy and bone marrow reserves, and CD19 may be related to the use of CD20 antibody therapy. Elevated sIL2-R levels are also associated with lymphoma activity.

As of December 1, 2021, third dose of vaccination has been discussed in worldwide based on the gradual decline of the vaccine titers after vaccination and this is expected to induce immunogenicity even for the patients with low titers of antibody after the second dose [21-23]. Our data on post-vaccination antibody titers in lymphoma patients may provide new insights into the selection of patients to be prioritized for the third vaccination and the importance of subsequent measurement of vaccine antibody titers. Another noteworthy finding is that patients with indolent lymphoma (CLL, Waldenström macroglobulinemia, marginal zone lymphoma FL) with infiltrative of lymphoma cells in the peripheral blood have low anti-S antibody titers, despite an absence of prior therapy. A previous report showed that untreated CLL patients had lower vaccine response than those in remission with treatment. Similar to CLL patients, patients with indolent lymphomas with lymphoma involvement in the peripheral blood also had an impaired response to the COVID-19 vaccine [10]. However, the preventive effect of vaccines is not only dependent on the amount of antibodies, but also on the 
speed and extent of the vaccine response to activate memory $\mathrm{B}$ cells and antigen-specific T cells against COVID-19 virus ${ }^{25}$, these factors need to be verified in actual clinical practice.

Limitations of this study include the relatively small sample size, as this report is from only two institutions; however, to date, it is one of the largest cohorts of patients with lymphoma in studies of this type ${ }^{9,11,13}$. Blood samples for antibody measurements were taken at the time of patients' visits to the hospital, therefore not all patients had blood samples taken regularly after vaccination. The response of $\mathrm{T}$ cells to vaccine has not yet studied. In addition, the follow-up period was short and the study did not cover the long-term decline in vaccine antibody titres after the second vaccination. Furthermore, questions remain about the risk of coronavirus infection in patients with inadequate production of antibodies to the vaccine, and about the relationship between severity of illness and antibody titres when infection occurs in these vulnerable individuals. However, to our knowledge, this is the first report, showed the clinical variables that can determine the COVID-19 vaccine response. Another strength of the study is the use of a large number of cases that allowed the comparison of vaccine titers among the different lymphoma subtypes.

In conclusion, we showed that patients with lymphoma had insufficient vaccine responses compared to the agematched cohort. The time between the completion of chemotherapy and vaccine administration, in addition to the percentage of CD19- and CD4-positive cells in the peripheral blood, and the serum concentration of $\operatorname{IgA}$ and $\operatorname{IgM}$ was important determinant of vaccine response. The data presented here on low responses to vaccines in lymphoma patients presented may provide useful information for appropriate vaccine administration strategies in the immunocompromised patients if comprehensively evaluated in combination with other immune parameters other than antibody titers in future.

Supplementary Information The online version contains supplementary material available at https://doi.org/10.1007/s12185-022-03305-z.

\begin{abstract}
Acknowledgements The authors would like to thank the patients with hematologic malignancy, their families, and the medical staff of the Department of Hematology of Kameda Medical Center, Department of Hematology of Kanawaza University. We also would like to thank Eri Suzuki. RN (assistant staff of Department of Hematology), and Kazuki Ueno, M.T., Hatsune Yanagida, M.T., and Harumi Ishikura, M.T. (Department of Laboratory Medicine) for antibody measurement. We also thank editage (https://www.editage.jp/) for English language editing and bioRender (https://biorender.com/) for making visual abstract.
\end{abstract}

Author contributions $\mathrm{KN}$ and KM: designed the study, wrote the manuscript, and provided patient care. $\mathrm{KN}$ and $\mathrm{SN}$ : collected the data and performed statistical analyses. MD, YU, and YO: measured the antibody titers. DM, TTsu, TTe, AK, RT, AF, DI, MT, and HT: provided patient care. KM: supervised the study.

\section{Declarations}

Conflict of interest The authors have no conflicts of interest to disclosure.

\section{References}

1. Guan W, Ni Z, Hu Y, Liang W, Ou C, He J, et al. Clinical characteristics of coronavirus disease 2019 in China. N Engl J Med. 2020;382:1708-20.

2. Polack FP, Thomas SJ, Kitchin N, Absalon J, Gurtman A, Lockhart S, et al. Safety and efficacy of the BNT162b2 mRNA Covid19 vaccine through 6 months. N Engl J Med. 2020;383:2603-15.

3. Baden LR, El Sahly HM, Essink B, Kotloff K, Frey S, Novak R, et al. Efficacy and Safety of the mRNA-1273 SARS-CoV-2 Vaccine. N Engl J Med. 2021;384:403-16.

4. Falsey AR, Sobieszczyk ME, Hirsch I, Sproule S, Robb ML, Corey L, et al. Phase 3 safety and efficacy of AZD1222 (ChAdOx1 nCoV-19) Covid-19 vaccine. N Engl J Med. 2021;385(25):2348-60.

5. Heath PT, Galiza EP, Baxter DN, Boffito M, Browne D, Burns F, et al. Safety and efficacy of NVX-CoV2373 Covid-19 vaccine. N Engl J Med. 2021;385:1172-83.

6. Khoury DS, Cromer D, Reynaldi A, Schlub TE, Wheatley AK, Juno JA, et al. Neutralizing antibody levels are highly predictive of immune protection from symptomatic SARS-CoV-2 infection. Nat Med. 2021;27:1205-11. https://doi.org/10.1038/ s41591-021-01377-8.

7. Lopez Bernal J, Andrews N, Gower C, Gallagher E, Simmons R, Thelwall S, et al. Effectiveness of Covid-19 vaccines against the B.1.617.2 (Delta) variant. N Engl J Med. 2021;385(7):585-94.

8. Pilishvili T, Gierke R, Fleming-Dutra KE, Farrar JL, Mohr NM, Talan DA, et al. Effectiveness of mRNA Covid-19 vaccine among U.S. Health Care Personnel. N Engl J Med [Internet]. 2021;1-13. Available from: http://www.ncbi.nlm.nih.gov/pubmed/34551224

9. Perry C, Luttwak E, Balaban R, Shefer G, Morales MM, Aharon A, et al. Efficacy of the BNT162b2 mRNA COVID-19 vaccine in patients with B-cell non-Hodgkin lymphoma. Blood Adv. 2021;5:3053-61.

10. Herishanu Y, Avivi I, Aharon A, Shefer G, Levi S, Bronstein $\mathrm{Y}$, et al. Efficacy of the BNT162b2 mRNA COVID-19 vaccine in patients with chronic lymphocytic leukemia. Blood. 2021;137:3165-73.

11. Crombie JL, Sherman AC, Cheng C-A, Ryan CE, Zon R, Desjardins M, et al. Activity of mRNA COVID-19 vaccines in patients with lymphoid malignancies. Blood Adv. 2021;5:3062-5.

12. Maneikis K, Šablauskas K, Ringelevičiūtė U, Vaitekėnaitė V, Čekauskienė R, Kryžauskaitė L, et al. Immunogenicity of the BNT162b2 COVID-19 mRNA vaccine and early clinical outcomes in patients with haematological malignancies in Lithuania : a national prospective cohort study. Lancet Hematol. 2021;8:583-92.

13. Parry H, McIlroy G, Bruton R, Ali M, Stephens C, Damery S, et al. Antibody responses after first and second Covid- 19 vaccination in patients with chronic lymphocytic leukaemia. Blood Cancer J. 2021;11:4-11. https://doi.org/10.1038/s41408-021-00528-x.

14. Herzog K, Odit T, Arie G, Naomi A, Sadovnik M, Harel L, et al. BNT162b2 COVID-19 vaccine is significantly less effective in patients with hematologic malignancies. Am J Hematol. 2021;96:1195-203.

15. Feng S, Phillips DJ, White T, Sayal H, Aley PK, Bibi S, et al. Correlates of protection against symptomatic and asymptomatic SARS-CoV-2 infection. Nat Med. 2021;27(11):2032-40. 
16. Benjamini-hochberg. Controlling the false discovery rate: a practical and powerful approach to multiple testing. J R Stat Soc Ser B. 1994;57:289-300.

17. Vijenthira A, Gong I, Betschel SD, Cheung M, Hicks LK. Vaccine response following anti-CD20 therapy: a systematic review and meta-analysis of 905 patients. Blood Adv. 2021;5:2624-43.

18. McLaughlin P, Grillo-López AJ, Link BK, Levy R, Czuczman MS, Williams ME, et al. Rituximab chimeric anti-CD20 monoclonal antibody therapy for relapsed indolent lymphoma: half of patients respond to a four-dose treatment program. J Clin Oncol. 1998;16:2825-33.

19. Sahin U, Muik A, Derhovanessian E, Vogler I, Kranz LM, Vormehr M, et al. COVID-19 vaccine BNT162b1 elicits human antibody and TH1 T cell responses. Nature. 2020;586:594-9. https://doi.org/10.1038/s41586-020-2814-7.

20. Grifoni A, Weiskopf D, Ramirez SI, Mateus J, Dan JM, Moderbacher $\mathrm{CR}$, et al. Targets of $\mathrm{T}$ cell responses to SARS-CoV-2 coronavirus in humans with COVID-19 disease and unexposed individuals. Cell. 2020;181:1489-1501 e15. https://doi.org/10. 1016/j.cell.2020.05.015.

21. Weakness L. Durability of Responses after SARS-CoV-2 mRNA1273 Vaccination. N Engl J Med. 2021;384:80-2.

22. Baudou E, Lespine A, Durrieu G, André F, Gandia P, Durand C, et al. Randomized trial of a third dose of mRNA-1273 vaccine in transplant recipients. N Engl J Med. 2021;385:1244-64.

23. Kamar N, Abravanel F, Marion O, Couat C, Izopet J, Del Bello A. Three doses of an mRNA Covid-19 vaccine in solid-organ transplant recipients. N Engl J Med. 2021;385:661-2.

Publisher's Note Springer Nature remains neutral with regard to jurisdictional claims in published maps and institutional affiliations. 